Akreditasi KEMENRISTEKDIKTI, Nomor: 28/E/KPT/2019
http://jurnal.stkippersada.ac.id/jurnal/index.php/vox

\title{
POLA ASUH ORANG TUA DAN IMPLIKASINYA TERHADAP PENDIDIKAN ANAK USIA DINI PADA SUBSUKU DAYAK INGGAR SILAT
}

\author{
Adpriyadi ${ }^{1} \&$ Sudarto $^{2}$ \\ ${ }^{1,2}$ PG-PAUD, STKIP Persada Khatulistiwa Sintang \\ Email: adpriyadi@gmail.com, sudarto.niarto@gmail.com
}

\section{INFO ARTIKEL \\ Riwayat Artikel: \\ Menerima : 20 Agustus 2019 \\ Revisi : : 17 Nopember 2019 \\ Diterima : 19 Nopember 2019}

\section{Kata Kunci:}

pola, asuh, subsuku, dayak, inggar

\section{Keywords:}

parenting, subtribes, dayak, inggar

\section{Korespondensi:}

Adpriyadi

PG-PAUD, STKIP Persada

Khatulistiwa Sintang

Email: adpriyadi@gmail.com

\begin{abstract}
ABSTRAK
Negara dengan tegas menjamin hak setiap warga negaranya untuk mendapatkan pendidikan. Kenyataannya, masih banyak ditemukan anak yang putus sekolah, termasuk pada Subsuku Dayak Inggar Silat. Masalah tersebut erat kaitannya dengan pola asuh yang diterapkan oleh orang tua. Oleh karena itu pola asuh anak usia dini pada masyarakat Subsuku Dayak Inggar Silat ini perlu dikaji secara mendalam. Penelitian ini bertujuan untuk mengetahui : pemahaman orang tua tentang pola asuh anak usia dini; pola yang diterapkan orang tua dalam pola asuh anak usia dini; faktor-faktor yang berpengaruh terhadap pola asuh anak pada masyarakat Subsuku Dayak Inggar Silat. Teknik Pengumpulan data dilakukan dengan teknik wawancara dan dokumentasi. Data yang diperoleh dianalisis secara deskriptif kualitatif. Hasil penelitian ini menunjukkan bahwa pemahaman orang tua pada Subsuku Dayak Inggar Silat termasuk kategori baik. Orang tua umumnya memahami bahwa pendidikan itu sangat penting. Hal ini dapat diketahui dari jawaban seluruh informan yang mengatakan bahwa menginginkan anak-anak mereka untuk tetap sekolah. Pola asuh yang diterapkan oleh sebagian besar masyarakat subsuku dayak inggar silat adalah pola asuh permisif dan pola demokratis. Faktor-faktor yang mempengaruhi pola asuh anak adalah: tingkat pendidikan orang tua, status sosial ekonomi, jumlah anak, usia dan jarak tempat tinggal ke sekolah.
\end{abstract}

\section{ABSTRACT}

The state firmly guarantees the right of every citizen to get an education. In fact, there are still many children who drop out of school, including those of the Inggar Silat Dayak Subsuku. The problem is closely related to parenting that is applied by parents. Therefore, the pattern of early childhood care in the Inggar Silat Sub-Dayak community needs to be studied in depth. This study aims to determine: parents' understanding of early childhood care patterns; patterns adopted by parents in early childhood care; factors that influence parenting in the Inggar Silat Sub-Dayak community. Data collection techniques carried out by interview and documentation techniques. The data obtained were analyzed descriptively qualitatively. The results of this study indicate that the understanding of parents in the Inggar Silat Dayak Subsuku is in the good category. Parents generally understand that education is very important. This can be seen from the answers of all informants who said that they want their children to go to school. The parenting practices adopted by most of the subtribes of Dayak Ingar Silat are permissive parenting and democratic patterns. Factors affecting parenting are: the level of parental education, socioeconomic status, number of children, age and distance of residence to school.

\section{PENDAHULUAN}

Pendidikan merupakan hal yang sangat penting, tetapi entah mengapa banyak sekali warga di Indonesia ini yang tidak mengenyam bangku pendidikan sebagaimana mestinya, 
sebagaimana halnya yang terjadi pada anak usia Dini pada Subsuku Dayak Inggar Silat Kecamatan Kayan Hilir Kabupaten Sintang. Berdasarkan hasil praobservasi pada bulan Juli tahun 2018 yang dilakukan dienam Desa yaitu Desa Sungai Garong, Desa Sungai Sintang, Desa Batu Netak, Desa Sungai Buaya, Desa Neran Baya, dan Desa Sungai Penga yang ada di kecamatan Kayan Hilir Kabupaten Sintang ditemukan masih banyak anak usia dini tidak melanjutkan sekolah lagi atau putus sekolah. Salah satu yang menjadi alasan mereka tidak sekolah lagi adalah karena orang tuanya bekerja ladang sehingga tidak ada yang menunggu anaknya. Adanya anak usia dini yang putus sekolah atau bahkan tidak bersekolah diduga erat kaitannya dengan pemahaman orang tua tentang pola pendidikan, termasuk pola asuh yang diterapkan. Oleh karena itu, pola asuh anak usia dini pada masyarakat Subsuku Dayak Inggar Silat Kecamatan Kayan Hilir Kabupaten Sintang ini perlu dikaji secara mendalam.

Berdasarkan tata bahasanya, pola asuh terdiri dari kata pola dan asuh. Menurut Kamus Umum Bahasa Indonesia, kata pola berarti model, sistem, cara kerja, bentuk (struktur yang tetap), sedangkan kata asuh mengandung arti menjaga, merawat, mendidik anak agar dapat berdiri sendiri.Petranto (Suarsini, 2013) menyatakan bahwa pola asuh orang tua merupakan pola perilaku yang diterapkan pada anak bersifat relatif konsisten dari waktu ke waktu.Pola perilaku ini dirasakan oleh anak, dari segi negatif maupun positif.Pola asuh yang ditanamkan tiap keluarga berbeda, hal ini tergantung pandangan dari tiap orang tua.
Gunarsa (2002) menyatakan bahwa pola asuh merupakan cara orangtua bertindak sebagai orangtua terhadap anak-anaknya di mana mereka melakukan serangkaian usaha aktif. Sedangkan menurut resolusi Majelis Umum PBB (Pamilu, 2007) fungsi utama keluarga adalah "sebagai wahana untuk mendidik, mengasuh, dan mensosialisasikan anak, mengembangkan kemampuan seluruhanggotanya agar dapat menjalankan fungsinya di masyarakat dengan baik, serta memberikan kepuasan dan lingkungan yang sehat guna tercapainy a keluarga, sejahtera”.

Pola asuh merupakan hal yang fundamental dalam pembentukan karakter.Teladan sikap orang tua sangat dibutuhkan bagi perkembangan anak-anak karena anak -anak melakukan modeling dan imitasi dari lingkungan terdekatnya.Keterbukaan antara orang tua dan anak menjadi hal penting agar dapat menghindarkan anak dari pengaruh negatif yang ada di luar lingkungan keluarga. Orang tua perlu membantu anak dalam mendisiplinkan diri (Sochib, 2000).Selain itu, pengisian waktu luang anak dengan kegiatan positif untuk engaktualisasikan diri penting dilakukan.Pengisian waktu luang juga merupakan salah satu wadah "katarsis emosi". Di sisi lain, orang tua hendaknya kompak dan konsisten dalam menegakkan aturan. Apabila ayah dan ibu tidak kompak dan konsisten, maka anak akan mengalami kebingungan dan sulit diajak disiplin. Hurlock (1999) membagi pola asuh orang tua ke dalam tiga macam yaitu:

Pola Asuh Permissif, demokratis dan otoriter Pola asuh permisif dapat diartikan sebagai pola 
perilaku orang tua dalam berinteraksi dengan anak, yang membebaskan anak untuk melakukan apa yang ingin di lakukan tanpa mempertanyakan. Pola asuh ini tidak menggunakan aturan-aturan yang ketat bahkan bimbinganpun kurang diberikan, sehingga tidak ada pengendalian atau pengontrolan serta tuntutan kepada anak. Kebebasan diberikan penuh dan anak diijinkan untuk member keputusan untuk dirinya sendiri, tanpa pertimbangan orang tua dan berperilaku menurut apa yang diinginkannya tanpa ada kontrol dari orang tua.

Prasetya (Anisa, 2005) menjelaskan bahwa pola asuh permissif atau biasa disebut pola asuh penelantar yaitu di mana orang tua lebih memprioritaskan kepentingannya sendiri, perkembangan kepribadian anak terabaikan, dan orang tua tidak mengetahui apa dan bagaimana kegiatan anak sehari-harinya. Dariyo (Annisa, 2005) juga mengatakan bahwa pola asuh permissifyang diterapkan orang tua, dapat menjadikan anak kurang disiplin dengan aturan-aturan sosial yang berlaku. Namun bila anak mampu menggunakan kebebasan secara bertanggung jawab, maka dapat menjadi seorang yang mandiri, kreatif, dan mampu mewujudkan aktualitasnya.

Gunarsa (2000) mengemukakan bahwa dalam menanamkan disiplin kepada anak, orang tua yang menerapkan pola asuh demokratis memperlihatkan dan menghargai kebebasan yang tidak mutlak, dengan bimbingan yang penuh pengertian antara anak dan orang tua, memberi penjelasan secara rasional dan objektif jika keinginan dan pendapat anak tidak sesuai. Dalam pola asuh ini, anak tumbuh rasa tanggung jawab, mampu bertindak sesuai dengan norma yang ada.

Dariyo (Anisa, 2005) mengatakan bahwa pola asuh demokratis ini, di samping memiliki sisi positif dari anak, terdapat juga sisi negatifnya, di mana anak cenderung merongrong kewibawaan otoritas orang tua, karena segala sesuatu itu harus dipertimbangkan oleh anak kepada orang tua.

Dalam praktiknya di masyarakat, tidak digunakan pola asuh yang tunggal, dalam kenyataan ketiga pola asuh tersebut digunakan secara bersamaan di dalam mendidik, membimbing, dan mengarahkan anaknya, adakalanya orang tua menerapkan pola asuh otoriter, demokratis dan permissif.Dengan demikian, secara tidak langsung tidak ada jenis pola asuh yang murni diterapkan dalam keluarga, tetapi orang tua cenderung menggunakan ketiga pola asuh tersebut. Hal ini sejalan dengan apa yang dikemukakan oleh Dariyo (Anisa, 2005), bahwa pola asuh yang diterapkan orang tua cenderung mengarah pada pola asuh situasional, di mana orang tua tidak menerapkan salah satu jenis pola asuh tertentu, tetapi memungkinkan orang tua menerapkan pola asuh secara fleksibel, luwes, dan sesuai dengan situasi dan kondisi yang berlangsung saat itu.

Menurut Gunarsa (2002), pola asuh otoriter yaitu pola asuh di mana orang tua menerapkan aturan dan batasan yang mutlak harus ditaati, tanpa memberi kesempatan pada anak untuk berpendapat, jika anak tidak mematuhi akan diancam dan dihukum. Pola asuh otoriter ini dapat menimbulkan akibat hilangnya kebebasan pada anak, inisiatif dan 
aktivitasnya menjadi kurang, sehingga anak menjadi tidak percaya diri pada kemampuannya.

Senada dengan Hurlock, Dariyo (Anisa, 2005), menyebutkan bahwaanak yang dididik dalam pola asuh otoriter, cenderung memiliki kedisiplinan dan kepatuhan yang semu.

Menurut Hurlock (1999) ada beberapa faktor yang dapat mempengaruhi pola asuh orang tua, yaitu karakteristik orang tua yang berupa: keperibadian Orang Tua dan keyakinan. Setiap orang berbeda dalam tingkat energi, kesabaran, intelegensi, sikap dan kematangannya. Karakteristik tersebut akan mempengaruhi kemampuan orang tua untuk memenuhi tuntutan peran sebagai orang tua dan bagaimana tingkat sensifitas orang tua terhadap kebutuhan anak-anaknya. Keyakinan yang dimiliki orang tua mengenai pengasuhan akan mempengaruhi nilai dari pola asuh dan akan mempengaruhi tingkah lakunya dalam mengasuh anak-anaknya.

Menurut

National

AssosiationEducation for Young Children (NAEYC), anak usia dini adalah sekelompok individu yang berada pada rentang usia antara 0 8 tahun. Masa pertumbuhan dan perkembangan anak usia dini harus dipantau secara terus menerus, sehingga akan dapat diketahui kematangan dan kesiapannya, baik yang menyangkut perkembangan dasar seperti perkembangan kemampuan bahasa, kognitif, dan motorik, maupun perkembangan pembiasaan yang akan membentuk kepribadian mereka nantinya.

Menurut Slamet Suyanto (2005: 56).Setiap anak bersifat unik. Setiap anak terlahir dengan potensi berbeda beda. Memiliki kelebihan, bakat, dan minat sendiri.Pada dasarnya setiap anak memiliki berbagai kecerdasan namun sangat jarang yang sangat sempurna memiliki delapan kecerdasan seperti pada teori multiple intelegent Howard Gardner 1998.

Nama Inggar merupakan nama sebuah sungai yang mengalir di kecamatan kayan hilir, kabupaten sintang. Diduga nama silat ini merupakan nama turunan dari nama Silat yang ada di Kabupaten Kapuas Hulu. Tempat pemukinan mereka berbatasan dengan Silat Hilir di Kecamatan Silat Hilir, Kapuas Hulu (Sujarni dkk, 2008: 33).

\section{METODE PENELITIAN}

Metode yang digunakan dalam penelitian ini adalah metode deskriptif. Sejalan dengan penjelasan tersebut, Subana dan Sudrajat (2005: 89) mengatakan bahwa penelitian deskriptif menuturkan dan menafsirkan data yang berkenaan dengan fakta, keadaan, dan fenomena yang terjadi saat penelitian berlangsung dan menyajikannya apa adanya.

Bentuk penelitian ini kualitatif sesuai dengan karakteristiknya, yakni memberikan data seperti apa adanya, menuntut peran serta peneliti, artinya peneliti juga berkedudukan sebagai instrumen dan data yang diambil tidak terlalu luas, tetapi menyeluruh, adanya ketercakupan, dan keleluasaan informasi yang diperlukan. Hal ini sejalan dengan pendapat Subana dan Sudrajat (2005: 17) mengatakan bahwa pada intinya penelitian kualitatif adalah penelitian yang dilakukan untuk 
mengungkapkan dan memaparkan penyelesaian suatu masalah.

Pendekatan yang digunakan dalam penelitian ini kualitatif sesuai dengan karakteristiknya, yakni memberikan data seperti apa adanya, menuntut peran serta peneliti, artinya peneliti juga berkedudukan sebagai instrumen dan data yang diambil tidak terlalu luas, tetapi menyeluruh, adanya ketercakupan, dan keleluasaan informasi yang diperlukan

Sumber data adalah subjek dari mana data yang diperoleh (Arikunto, 2006: 129). Sumber data dalam penelitian ini adalah Pola Asuh Orang Tua dan Implikasinya terhadap Pendidikan anak Usia dini Pada Subsuku Dayak Inggar Silat Kecamatan Kayan Hilir Kabupaten Sintang

Data dalam penelitian ini meliputi katakata atau cerita langsung dari para informan penelitian, tindakan atau pola fikir para orang tua tentang pendidikan anak-anaknya dan datadata yang berkaitan dengan pendidikan.Keterangan berupa kata-kata atau cerita langsung dari informan dijadikan sebagai data utama (data primer), sedangkan tulisan atau data dari berbagai dokumen dijadikan sebagai data pelengkap (data sekunder).

Teknik yang digunakan dalam penelitian ini Observasi langsung ke lapangan dan wawancara. Pada tahap ini peneliti melakukan pengamatan terhadap objek yang akan peneliti teliti. Dengan melakukan observasi peneliti telah mendapatkan gambaran tentang langkah-langkah dalam melakukan penelitian, bentuk data yang akan diperoleh, dan gambaran tentang pelaporan hasil penelitian. Wawancara peneliti lakukan untuk mencari dan mendapatkan data-data penunjang penelitian. Wawancara peneliti lakukan kepada informan kunci dan kepada masyarakat yang mengetahui tentang pola asuh. Alat pengumpulan data yaitu lembar observasi dan pedoman wawancara

keabsahan data menggunakan teknik triangulasi, yakni pengecekan keabsahan data dengan cara melakukan perbandingan dengan hal-hal diluar data, misalnya membandingkan hasil pengamatan dengan hasil wawancara. Hal tersebut sesuai dengan pendapat Moleong (2007: 330) mengatakan bahwa triangulasi adalah teknik pemeriksaan data yang memanfaatkan sesuatu yang lain di luar data itu untuk keperluan pengecekan atau sebagai pembanding terhadap data itu.

Penelitian ini menggunakan teknis analisis model interaktif (interactive model of analysis) dari Miles dan Huberman. Pada model analaisis interaktif ini peneliti bergerak pada tiga komponen, yaitu reduksi data (data reduction), penyajian data (data display) dan penarikan kesimpulan (verification).

\section{HASIL DAN PEMBAHASAN}

Dari beberapa orang informan yang diwawancarai tersebut dapat ditarik suatu kesimpulan bahwa warga Subsuku Dayak Inggar Silat Kecamatan Kayan Hilir Kabupaten Sintang umumnya sudah memahami betapa pentingnya pendidikan bagi anak usia dini, baik bagi orang tua yang masih berusia muda atau sudah berusia tua, baik bagi mereka yang mempunyai anak sedikit maupun bagi orang tua yang mempunyai anak banyak, baik mereka yang tidak pernah mengenyam pendidikan 
maupun bagi mereka yang pernah mengenyam pendidikan.

Harapan dari Setiap orang tua selalu menginginkan yang terbaik bagi anak-anaknya. Hal ini membuat orang tua memberikan pola asuh tertentu sesuai harapan mereka terhadap anaknya.

Dari penelitian ini terungkap bahwa beberapa pola asuh yang diterapkan oleh orang tua Subsuku Dayak Inggar Silat Kecamatan Kayan Hilir Kabupaten Sintang yaitu: pola asuh permisif dan demokratis. Diterapkannya pola asuh permisif terlihat dari beberapa jawabab informan kepada peneliti. Ibu $\mathrm{C}$ mengatakan bahwa: "saya senang anak-anak ingin sekolah, tapi saya tidak bisa memantau mereka apakah sekolah dengan baik atau tidak karena saya sibuk bekerja ke ladang dan perginya subuh, sehingga saya tidak dapat memastikan mereka pergi sekolah dengan benar atau tidak. Kelihatanya mereka kesekolah dengan keinginan sendiri saja."

Pernyataan dari informan lainnya bapak J menyatakan bahwa" saya tergantung pada diri anak jika mau masa depannya baik maka harus sekolah, tapi jika tidak mau sekolah juga terserah mereka, nanti juga mereka yang punya masa depan."

Dapat disimpulkan pola asuh yang diterapkan dari informan di atas Pola asuh bersifat permisif (serba membolehkan), tidak mengendalikan, kurang menuntut. Orang Tua tidak terorganisasi dengan baik atau tidak efektif dalam menjalankan rumah tangga, lemah dalam mendisiplinkan dan mengajar anak-anak, hanya menuntut sedikit dewasa dan hanya member sedikit perhatian dalam melatih kemandirian dan kepercayaan diri. Mereka dengan pola asuh permisif dibiarkan mengatur tingkah laku mereka sendiri dan membuat keputusan sendiri.

Selain pola asuh permisif juga tergambarkan pola asuh demokratis yang diterapkan Subsuku Dayak Inggar Silat Kecamatan Kayan Hilir Kabupaten Sintang. Sebagaimana telah dikemukakan bahwa orang tua yang dikategorikan ke dalam pola asuh demokratis adalah orang tua yang berusaha untuk mengarahkan anak agar dapat bertingkah laku secara rasional, dengan memberikan penjelasan terlebih dahulu pada anak. Orang tua memberikan penjelasan mengenai tuntutan dan disiplin yang ditetapkan, tetapi tetap menggunakan wewenangnya atau memberikan hukuman jika dianggap perlu. Orang tua memberlakukan serangkaian standar dan peraturan yang dilakukan secara sungguh sungguh dan konsisten. Orang tua demokratis menggunakan kontrol yang tinggi disertai kehangatan yang tinggi.

Berdasarkan hasil wawancara dengan salah seorang informan yaitu ibu G menyatakan bahwa " anak-anak harus tetap sekolah untuk masa depan yang lebih baik, karena saya tamat SMP maka paling tidak anak saya harus lulus SMA, bahkan harus melebihi lebih tinggi lagi, saya menyampaikan kepada anak-anak jangan sampai putus sekolah. Informan lain yaitu bapak $\mathrm{H}$ menyatakan bahwa" saya mengharuskan anak-anak terus sekolah setinggi-tingginya gapailah impian kalian sesuai bakat dan minat kalian". Orang tua seperti ini bersikap rasional dan selalu 
mendasari tindakannya pada pemikiran. Orang tua tipe ini juga bersikap realistis terhadap kemampuan anak. Mereka tidak berharap lebih pada kemampuan yang dimiliki anak. Orang tua demokratis juga memberikan kebebasan kepada anak untuk memilih. Mereka juga membebaskan anak dalam memutuskan suatu tindakan. Apabila hendak menasehati, orangtua demokratis selalu melakukannya dengan pendekatan yang hangat.

Faktor-faktor yang mempengaruhi pola asuh para orang tua pada masyrakat Subsuku Dayak Inggar Silat Kecamatan Kayan Hilir Kabupaten Sintang adalah tingkat pendidikan orang tua, status sosial ekonomi, jumlah anak, usia dan jarak tempat tinggal ke sekolah.

\section{SIMPULAN}

Berdasarkan hasil penelitian dan analisis data yang dilakukan secara umum dapat disimpulkan pemahaman orang tua tentang pola asuh pada Subsuku Dayak Inggar Silat Kecamatan Kayan Hilir Kabupaten Sintang termasuk kategori baik. Fakta ini diperoleh dari jawaban para informan yang menginginkan anak-anak mereka untuk tetap sekolah dan mengapai citacita setinggi tinginya demi masa depan yang lebih baik. Pola asuh yang diterapkan oleh para orang tua yaitu pola asuh permisif dan demokratis. Faktor yang mempengaruhi pola asuh yaitu tingkat pendidikan orang tua, status sosial ekonomi, jumlah anak, usia dan jarak tempat tinggal ke sekolah.

\section{DAFTAR RUJUKAN}

Adawiah, Rabiatul. 2017. Pola Asuh Orang Tua Dan Implikasinya Terhadap Pendidikan Anak, Artikel (Online)(https://media.neliti.com/medi
a/publications/121261-ID-pola-asuhorang-tua-dan-implikasinya-ter.pdf, diakses 23 Agustus 2018).

Alloy, Sujarni dkk. 2008. Mozaik Dayak Keberagaman Subsuku dan Bahasa Dayak di Kalimantan Barat. Pontianak: Institut Dayakologi.

Ani ,Siti Anissah. 2011. Pola Asuh Orang Tua Dan Implikasinya Terhadap Pembentukan Karakter Anak, Artikel (Online)( https://journal.uniga.ac.id/index.php/JP /article/view/43, diakses 23 Agustus 2018.

Anisa, Siti. 2005. Kontribusi Pola Asuh Orang tua terhadap Kemandirian Siswa Kelas II SMA Negeri 1 Balapulang Kabupaten Tegal Tahun Pelajaran 2004/2005. Skripsi. Universitas Negeri Semarang.

Arikunto, Suharsimi. 2013. Prosedur Penelitian Suatu Pendekatan Praktik. Jakarta: Rineka Cipta.

Gunarsa, Singgih. 2002, Psikologi Perkembangan Anak dan Remaja, Jakarta: Gunung Mulia.

Hurlock, E.B.1999. Chlid Developmant Jilid II, terjemahan Tjandrasa, Jakarta: Erlangga.

Moleong, Lexi J. 2012. Metode Penelitian Kualitatif. Bandung: Remaja Rosdakarya Offset.

Pemilu, Anik. 2007. Mendidik Anak Sejak Dalam Kandungan. Panduan Lengkap Cara Mendidik Anak Untuk Orang Tua. Citra Media: Yogyakarta

Sochib, Moch. 2000. Pola Asuh Orang Tua. Dalam Membantu Anak Mengembangkan Disiplin Diri. RinekaCipta:Jakarta.

Suarsini, Desy. 2013. Pola Asuh Orang Tua, Artikel

(Online)(http;//desysuar.blogspot.com, di akses 22 Agustus 2018. 
Subana, M., Sudrajat, 2011, Dasar - Dasar Penelitian Ilmiah, Bandung: Pustaka Setia. 